\title{
БОСНИЯ И ГЕРЦЕГОВИНА ВО ВРЕМЯ И ПОСЛЕ ВСЕОБЩИХ ВЫБОРОВ
}

Аннотация. Общеизвестно, что предвыборная риторика и послевыборная политика заметно отличаются. Прошедшие 7 октября 2018 г. всеобщие выборы в Боснии и Гериеговине и последующее развитие событий демонстрируют, насколько разительно может быть данное расхождение. Второй урок выборов: сверхактивные попытки Вашингтона и Брюсселя повлиять на избирательньй прочесс, как и следовало ожидать, оказались контрпродуктивными. Если рассуждать в категориях геополитического соперничества, эти выборы выиграла Москва, практически не прикладывая никаких усилий. Но её противники не собираются наблюдать, сложа руки. Они проиграли, сражаясь «против Додика». Возможно, они попьтаются отыграться, борясь «за Додика».

Ключевые слова: Босния и Гериеговина, всеобщие выборы, результаты, последствия.

7 октября 2018 г. прошли (при явке в 50\%) всеобщие выборы в Боснии и Герцеговине 1 . Избирались органы власти всех степеней как на общегосударственном уровне, так и в составляющих её образованиях: Федерации БиГ (населённой преимущественно бошняками-мусульманами и хорватами) и Республике Сербской (где подавляющее большинство - сербы). Особое значение выборам придали несколько ключевых сюжетов. Среди избирателей-сербов главная интрига задавалась давним противостоянием многолетнего лидера Республики Сербской (РС), её президента М. Додика, главы Союза независимых социал-демократов (СНСД; находящегося у власти 12 лет) и оппозиционной коалиции «Союз за перемены» во главе с сербским членом Президиума БиГ М. Иваничем. Противники М. Додика пользовались нескрываемыемыми симпатиями западных посольств, Вашингтона и Брюсселя. Он стал для них бельмом на глазу из-за своих явно демонстрируемых пророссийских симпатий и твёрдого противостояния западному давлению на РС. На выборах сербского члена Президиума БиГ борьба шла между М. Додиком и решившим ещё раз повторить свой мандат М. Иваничем. При избрании президента РС соперничали выдвиженка М. Додика, занимавшая пост премьера РС Ж. Цвиянович и лидер Сербской демократической партии - крупнейшей силы оппозиции В. Говедарица. Противоборство правившего в республике СНСД вместе с его союзниками (Социалистическая партия и Демократический народный союз) и оппозиционной коалиции «Союз за перемены» (Сербская демократическая партия, Партия демократического прогресса М. Иванича и Народное демократическое движение) продолжилось и на выборах парламента РС, и депутатов Палаты представителей на общегосударственном уровне.

В Федерации БиГ в избирательной кампании внимание привлекали два момента. Удастся ли националистическо-исламистской Партии демократического действия во главе с Б. Изетбеговичем (сыном её основателя А. Изетбеговича) сохранить своё доминирующее положение

\footnotetext{
(с) Кандель Павел Ефимович - кандидат исторических наук, ведущий научный сотрудник Отдела социальных и политических исследований ИЕ РАН. Адрес: 125009, Россия, Москва, Моховая ул., д. 11, стр. 3. E-mail: xpekan@yandex.ru.
}

DOI: http://dx.doi.org/10.15211/vestnikieran220197378

${ }^{1}$ Opći izbori 2018. godine-Potvrđeni rezultati. URL: http://www.izbori.ba/rezultati_izbora (дата обращения: 15.03. 2019). 
среди избирателей-бошняков, или же её потеснит считающийся левоцентристским т.н. Боснийско-герцеговинский блок (Социал-демократическая партия, Демократический фронт и Наша партия)? Они стремятся позиционировать себя вне национальных координат, хотя и по своему составу и электорату представляют собой за малыми исключениями политические организации бошняков. Кто займёт место хорватского члена Президиума: лидер Хорватского демократического содружества - наиболее авторитетной среди боснийских хорватов партии - Д. Чович, баллотировавшийся на второй срок, или его основной соперник - лидер Демократического фронта Ж. Комшич, уже занимавший этот пост в 2006 и в 2010 гг. Его ХДС обвиняет в забвении интересов хорватов и считает подставной фигурой, проталкиваемой бошняками. Избирательная кампания носила «традиционный» характер: ведущие партии и в бошняцкой (ПДД), и в сербской (СНСД), и в хорватской среде (ХДС) активно использовали националистическую риторику и соревновались, кто больше преуспеет в этнической мобилизации «своего» электората. Фактически же они помогали друг другу, способствуя подобному же процессу в «инородной» среде.

К разочарованию Вашингтона и Брюсселя выборы завершились очередной и полной победой «злокозненного» М. Додика и его партии на всех уровнях и сокрушительным поражением оппозиции. При избрании сербского члена Президиума БиГ он получил 53,8\% голосов, а его соперник М. Иванич - 42,7\%. Поскольку М. Додик собрал и наибольшее число голосов, он к тому же стал первым (сменяемым через 8 месяцев) Председателем Президиума БиГ, что дало ему право предложить кандидатуру главы правительства БиГ из своей партии. Его однопартийка и экс-премьер РС Ж. Цвиянович заняла пост президента РС, победив своего соперника из оппозиции со счётом 47,5\% против 42,9\%. В Народной Скупщине РС (83 депутата) правящая коалиция во главе с СНДС увеличила число мандатов с 42 до 47, что обеспечило избрание премьера РС также из рядов СНДС. Им стал Р. Вишкович. Ведущая оппозиционная сила - Сербская демократическая партия потерпела тяжёлое поражение, завоевав лишь 13 мандатов (прежде 23). В Палате представителей парламента БиГ (42 депутата, из которых квота РС - 14 депутатов) СНСД получил 6 мандатов, его союзники ДНС и СП - по одному. Его оппоненты и здесь оказались в меньшинстве: Сербская демократическая партия с союзниками - 3, ПДП - 2. Разброд в лагере оппозиции после поражения и удачные тактические манёвры М. Додика - признанного мастера политической интриги, позволили ему привлечь на свою сторону часть заколебавшихся оппозиционеров, переманить Народное демократическое движение, расширить парламентское большинство в Народной скупщине РС и консолидировать сербских депутатов Палаты представителей на своей платформе. Чтобы окончательно «зацементировать» сербские позиции на общегосударственном уровне, М. Додик даже предложил места в правительстве БиГ проигравшим: СДС и ПДП. Обе отказались, но обещали сотрудничать в защите интересов Республики Сербской. И в Палате народов парламента БиГ из 5 депутатов-сербов 4 из СНСД. Успеху явного фаворита выборов сильно помогло то обстоятельство, что партии на этом политическом пространстве, по меткому замечанию одного из аналитиков, не столько «клубы фанатов», сколько «бюро по трудоустройству». Оказавшись не при власти хотя бы на местном уровне, быстро утрачивают и привлекательность и сторонников ${ }^{1}$. Торжество М. Додика несколько омрачают массовые демонстрации протеста в связи с вызвавшим большой общественный резонанс загадочным убийством студента Д. Драгичевича и недостаточной активностью полиции в расследовании этого преступления. Эту историю при явной информационной и политической поддержке Брюсселя и Вашингтона пытаются

\footnotetext{
${ }^{1}$ Бижић С. Стара опозиција у РC на издисају, нова се (не) назире. URL: http://www.nspm.rs/sudbina-dejtonskebih-i-republika-srpska/stara-opozicija-u-rs-na-izdisaju-nova-se-ne-nazire.html (дата обращения: 15.03.2019).
} 
активно использовать представители зарождающейся «новой оппозиции» для наращивания политического капитала. Но в органах власти «новые оппозиционеры» представлены лишь отдельными депутатами и пока вряд ли способны создать серьёзную политическую угрозу М. Додику. В среде бошняков Партии демократического действия удалось, хотя и не без труда, про-вести на пост члена Президиума БиГ своего кандидата Ш. Джаферовича (36,6\% голосов). Но его ближайший соперник из Социал-демократической партии набрал немногим меньше голосов $(33,5 \%)$. В Палате представителей БиГ (9 мест) и в Палате представителей Федерации БиГ (27 мест) ПДД подтвердила репутацию крупнейшей силы, но остальные политические партии бошняков поначалу вознамерились «дружить против» неё и получили достаточное ко-личество мандатов, чтобы блокировать её соединёнными усилиями. Ещё большего успеха со-перники ПДД достигли на региональном уровне - во многих кантонах Федерации БиГ, которые имеют свои парламенты и правительства, располагающие немалыми средствами и компетенциями. Пошли было разговоры, что левоцентристский блок (32 места) вместе с находив-шимся также в оппозиции Союзом за лучшее будущее ( 8 мест) под руководством медиа-маг-ната Ф. Радончича и рядом минипартийных образований, созданных «дисидентами» из ПДД, способны образовать коалиционный кабинет в Федерации БиГ, отстранив ведущую партию от власти. Но развитие событий вскоре показало, что боснийский политический покер играет-ся по иным правилам, и при анализе важно не столько отслеживать переменчивые заявления игроков, сколько «следить за руками».

Ожидаемый конфуз случился на выборах хорватского члена Президиума. Ж. Комшича удалось протащить на этот пост (52,6\% голосов против $36,1 \%$ у его соперника лидера ХДС Д. Човича). Но победа, достигнутая голосами избирателей-бошняков, оказалась «пирровой». Её прямым следствием стал затяжной политический кризис и институциональный паралич и в Федерации БиГ и на общегосударственном уровне. Д. Чович, поддержанный ХДС и всеми хорватскими организациями в БиГ, квалифицировал избрание Ж. Комшича как «неконституционное, незаконное, нелегальное и нелегитимное» ${ }^{1}$. Хорватские партии БиГ давно требовали изменения закона о выборах, чтобы исключить подобные варианты, но добиться этого им не удалось. После выборов они тем более не собирались отказываться от своего требования. Но без представителей хорватов невозможно сформировать ни Палату народов (как в Федерации БиГ, так и на общегосударственном уровне), ни правительства. Позицию хорватских патий БиГ поддержали премьер и президент соседней Хорватии (где у власти также находится ХДС), которая инициировала рассмотрение данной темы на Совете ЕС. С Д. Човичем солидаризировался и М. Додик. Между ними ещё до выборов установился довольно тесный контакт, который в послевыборной ситуации тем более укрепился. Д. Чович решил ещё выше поднять ставки, заявив: хорватские партии БиГ продолжат выступать за федерализацию государства ${ }^{2}$. Это предполагает создание, наряду с двумя существующими - Федерацией БиГ и РС, третьего, хорватского образования - давнюю мечту боснийских хорватов и «страшный сон» для босняков. Европейский союз при поддержке США определил свои приоритеты в следующей последовательности: скорейшее формирование органов власти, продолжение проевропейских реформ и изменение избирательного закона. В конечном счёте ХДС, которому обещали пересмотреть злополучный закон и гарантировали места в кабинетах и на уровне

\footnotetext{
1 Цит. по: Mostarski sindrom. URL: https://www.dw.com/sr/mostarski-sindrom/a-46015972 (дата обращения: 15.03.2019).

2 Драган Човић: Решење за БиХ је федерализација, то је једини исправни пут који земљу може усмерити према евроатлантским интеграцијама. Нова српска политичка мисао. 01. Фебруар 2019. URL: http://www.nspm.rs/hroni $\mathrm{ka} /$ dragan-covic-resenje-za-bih-je-federalizacija-to-je-jedini-ispravni-put-koji-zemlju-moze-usmeriti-prema-evroatlants kim-integracijama.html (дата обращения: 15.03.2019).
} 
федерации, и на общегосударственном уровне, снял требование отмены выборов и пошёл на образование коалиционных правительств с ПДД и СНСД. При избрании депутатов Палаты народов представители трёх этих партий голосовали фактически солидарно.

Трудно решаемой проблемой оставалась расстановка сил в бошняцком сегменте политического поля. Провозгласив после выборов противоестественное желание создать коалиционное правительство вместе с СНСД М. Додика и ХДС Д. Човича, против которых Б. Изетбегович и строил свою предвыборную кампанию, он вернул себе лидирующую позицию среди бошняцких партий и сорвал попытки изолировать ПДД. Но для формирования удобного большинства и правительств на общегосударственном, федеральном и особенно региональном (кантональном) уровнях, потребовались дополнительные партнёры. Такое предложение он и адресовал оппозиционному Боснийско-герцеговинскому блоку и Союзу за лучшее будущее Ф. Радончича. Те поначалу принципиально отвергли «сговор с националистами». Тогда Б. Изетбегович совершил ещё один вроде бы необъяснимый политический кульбит: заявил о намерении оспорить в Конституционном суде само наименование Республики Сербской, будто бы нарушающее равноправие народов. Последовала ожидаемо жёсткая реакция другой стороны: М. Додик отвечал, что в случае нарушения конституционного статуса РС последует референдум о её независимости ${ }^{1}$. Инициативу Б. Изетбеговича осудили и Высокий представитель международного сообщества в БиГ, и Руководящий комитет Совета по выполнению мирных соглашений, и ОБСЕ 2 . Казалось бы, после подобного о какой-либо коалиции с СНСД можно забыть. Но на боснийской политической сцене обмен риторическими выпадами и угрозами является обиходным средством укрепления электоральных и политических позиций, привычным инструментом взаимного давления элит трёх национальных общин, что отнюдь не исключает их последующего (а иной раз и одновре́менного) прагматического сотрудничества.

Поступок Б. Изетбеговича позволил ему вызвать раскол в среде бошняцкой оппозиции и интенсифицировать переговоры с возможными партнёрами «во имя государственных интересов», а М. Додику - сплотить все сербские партии для защиты Республики Сербской. И хотя оппозиционные политики не скрывали своих подозрений, что речь идёт о взаимовыгодной игре «дуэтом» по предварительному сговору ${ }^{3}$, они не рискнули остаться в стороне от поднятой волны этнической консолидации. Неготовность противиться искушению властью получала легитимное обоснование «высшими национальными интересами».

Показательную эволюцию претерпела позиция СЛБ Ф. Радончича. Первоначальное категорическое нет коалиции с ПДД через несколько месяцев сменилось изложением «государственнических» мотивов, которые делают подобный союз целесообразным ${ }^{4}$. Переговоры Б. Изетбеговича с минипартиями «диссидентов» из ПДД породили подозрения, что власть может быть сформирована и без левоцентристов. После этого обнаружились трещины и в их единстве. «Наша партия» настаивала на том, чтобы остаться в оппозиции, в Социал-демократической партии наметился раскол, а Демократический фронт Ж. Комшича стал склоняться к переговорам с ПДД. Хотя три эти партии к середине февраля всё же подтвердили общее на-

\footnotetext{
${ }^{1}$ Dvojac koji BiH vodi u propast. URL: https://www.dw.com/sr/dvojac-koji-bih-vodi-u-propast/a-47206289 (дата обращения: 15.03.2019).

PIK: Inicijativa SDA pogrešan korak, Rusija tražila jaču osudu. URL: http://www.tanjug.rs/fullview.aspx?izb=457654 (дата обращения: 15.03.2019).

${ }^{3}$ Tanka je linija između opozicije i vlasti: Politički maneveri i promjene dresova u RS-u. URL: https://www.klix.ba/vij esti/bih/tanka-je-linija-izmedju-opozicije-i-vlasti-politicki-maneveri-i-promjene-dresova-u-rs-u/190215039 (дата обращения: 15.03.2019).

${ }^{4}$ Kako je SBB mijenjao mišljenje: Od «nema teoretske šanse sa SDA» do «državničkog pristupa». URL: https://www. klix.ba/vijesti/bih/kako-je-sbb-mijenjao-misljenje-od-nema-teoretske-sanse-sa-sda-do-drzavnickog-pristupa/190215037 (дата обращения: 15.03.2019).
}

Научно-аналитический вестник ИЕ РАН, 2019, №2 
мерение не входить во власть, их единство оказалось недолговечно. Демократический фронт покинул оппозицию и договорился с ПДД. Но попытки выторговать у сербов и хорватов лишнее место в кабинете вновь завели переговоры в тупик. В итоге спустя полгода после выборов нет правительства ни на общегосударственном уровне, ни в Федерации БиГ, а страна до конца года лишилась места в ПАСЕ из-за неспособности сформировать делегацию.

Помимо внутренних хитросплетений на боснийской политической сцене, дополнительные препятствия формированию власти создали внешние факторы. Хотя и ЕС и США постоянно требуют от боснийских политиков поскорее закончить создание властных институтов и заняться наконец делом, суля вознаградить усердие возможным предоставлением БиГ статуса кандидата в Евросоюз, другие их действия прямо противоречили поставленной цели. 5 декабря 2018 г. министры иностранных дел стран НАТО сообщили о готовности одобрить первую Ежегодную национальную программу БиГ по сотрудничеству с НАТО, что открывало путь для активизации Плана действий по подготовке к членству (МАР). Но Народная Скупщина РС 18 октября 2017 г. приняла резолюцию, провозгласившую «военную нейтральность РС в отношении существующих военных союзов до возможного референдума, на котором будет принято окончательное решение». Подчёркнуто, что её выбор будет координироваться с Сербией, также декларирующей «военную нейтральность» ${ }^{1}$. М. Додик не раз заявлял, что не намерен отступать от этой позиции. В то же время бошняцкие политические силы своё согласие на создание кабинета и назначение премьера из СНСД обуславливали именно её принятием. Таким образом «несвоевременная» инициатива НАТО затянула процесс формирования власти и на общегосударственном уровне и в Федерации БиГ. Вероятно, инициаторы этой затеи понадеялись, что соблазн получить власть и на общегосударственном уровне сделает М. Додика более податливым.

Нельзя сказать, что расчёты вовсе безосновательны. В прошлом лидер СНСД говаривал, что он лично не против вступления страны даже в НАТО, но при проведении референдума и не за счёт полномочий РС. И в нынешней ситуации он подал сигналы, призванные засвидетельствовать гибкость и прагматизм. По его словам, о «европейском пути» (в отличие от НАТО) в стране существует полное единогласие. Торжественное вручение в Брюсселе долго согласовывавшихся ответов на 656 дополнительных вопросов анкеты Еврокомиссии призвано подтвердить конструктивную роль РС и его самого «в процессе евроинтеграции». Боснийские лидеры надеются на скорое предоставление БиГ статуса кандидата в ЕС (его имеют все государства региона, за исключением Косово). И М. Додик и президент РС Ж. Цвиянович, отметили, что взаимодействие с НАТО по модели Австрии или Финляндии при сохранении нейтрального статуса может подойти и БиГ ${ }^{2}$. Вряд ли это обрадовало функционеров Североатлантического альянса, но подобные суждения достаточно неоднозначны. Ведь и Финляндия, и Австрия, и даже Сербия, на чей пример ссылаются лидеры РС, сохраняя нейтральный статус, интенсивно сотрудничают с блоком. Таким образом, с одной стороны демонстрируется солидарность с Сербией, решимость защищать нейтралитет БиГ, с другой - даётся подсказка: как можно достичь согласия в вопросе о НАТО и разрешить институциональный кризис в БиГ. На большее М. Додик в сегодняшних условиях вряд ли готов. И потому, что не хочет лишиться поддержки Москвы - значимого фактора своих электоральных успехов и опоры в

\footnotetext{
${ }^{1}$ Резолуција о заштити уставног поретка и проглашењу војне неутралности Републике Cpпске. URL: http:// www.narodnaskupstinars.net/?q=ci/акти/остали-акти/резолуција-о-заштити-уставног-поретка-и-проглашењувојне-неутралности-републике-српске (дата обращения: 15.03.2019).

${ }^{2}$ Цит. по: Дурмановић С. БиХ, НАТО и Србија - где води Вучићево «разграничење» на КиM? URL: http://91.222 .7.44/sudbina-dejtonske-bih-i-republika-srpska/bih-nato-i-srbija-gde-vodi-vucicevo-razgranicenje-na-kim.html (дата обращения: 15.03.2019).
}

Научно-аналитический вестник ИЕ РАН, 2019, №2 
противостоянии давлению Вашингтона и Брюсселя. И чтобы не осложнять и без того не простые взаимоотношения с властями Сербии. Неразумно, наконец, связывать себе руки накануне окончательного разрешения «косовской проблемы», каким бы оно не было. Если рассуждать в категориях геополитического соперничества, прошедшие выборы выиграла Москва, практически не прикладывая никаких усилий. Но её противники не собираются наблюдать, сложа руки. Они проиграли, сражаясь «против Додика». Возможно, они попытаются отыграться, борясь «за Додика».

\section{References}

Бижић С. Стара опозиција у PC на издисају, нова се (не) назире. URL: http://www.nspm. rs/sudbinadejtonske-bih-i-republika-srpska/stara-opozicija-u-rs-na-izdisaju-nova-se-ne-nazire.html.

Драган Човић: Решење за БиХ је федерализација, то је једини исправни пут који земљу може усмерити према евроатлантским интеграцијама. URL: http://www.nspm.rs/hronika/ dragan-covic-resenjeza-bih-je-federalizacija-to-je-jedini-ispravni-put-koji-zemlju-moze-usmeriti-pre ma-evroatlantskimintegracijama.html.

Дурмановић С. БиХ, НАTO и Србија - где води Вучићево «разграничење» на КиM? URL: http://91.222.7.144/sudbina-dejtonske-bih-i-republika-srpska/bih-nato-i-srbija-gde-vodi-vucicevorazgranicenje-na-kim.html.

Резолуција о заштити уставног поретка и проглашењу војне неутралности Републике Српске. URL:http://www.narodnaskupstinars.net/?q=ci/акти/остали-акти/резолуција-о-заштити-уставногпоретка-и-проглашењу-војне-неутралности-републике-српске.

Dvojac koji $\mathrm{BiH}$ vodi u propast. URL: https://www.dw.com/sr/dvojac-koji-bih-vodi-u-propast/a47206289.

Kako je SBB mijenjao mišljenje: Od «nema teoretske šanse sa SDA» do «državničkog pristupa». URL: https://www.klix.ba/vijesti/bih/kako-je-sbb-mijenjao-misljenje-od-nema-teoretske-sanse-sa-sda-dodrzavnickog-pristupa/190215037.

Mostarski sindrom. URL: https://www.dw.com/sr/mostarski-sindrom/a-46015972.

Opći izbori 2018. godine-Potvrđeni rezultati. URL: http://www.izbori.ba/rezultati_izbora.

PIK: Inicijativa SDA pogrešan korak, Rusija tražila jaču osudu. URL: http://www.tanjug.rs/fullview.aspx?izb=457654.

Tanka je linija između opozicije i vlasti: Politički maneveri i promjene dresova u RS-u. URL: https://www.klix.ba/vijesti/bih/tanka-je-linija-izmedju-opozicije-i-vlasti-politicki-maneveri-i-promjenedresova-u-rs-u/190215039.

\section{Bosnia and Herzegovina in the Course of General Elections and After}

Author. Pavel Kandel, Candidate of Sciences (History), Leading Researcher, Department of Social and Political Studies. Institute of Europe, Russian Academy of Sciences. Address: 11-3, Mokhovaya str., Moscow, Russia, 125009. E-mail: xpekan@yandex.ru.

Abstract. It is commonly known that pre-election rhetoric and subsequent policy after elections differ well visibly. The general elections in Bosnia and Herzegovina (October 7, 2018) and further developments in the republic demonstrate how striking such divergence can be. The author comes to a conclusion that overactive attempts exercised by Washington and Brussels in order to influence the electoral process, as expected, were counterproductive. In terms of geopolitical rivalry, these elections were won by Moscow, almost without making any efforts. Nevertheless, her rivals are not going to watch idly further developments. They lost their fighting «against Dodik», but they will try to recoup, fighting for influence on him.

Key words: Bosnia and Herzegovina, general elections, results, consequences

DOI: http://dx.doi.org/10.15211/vestnikieran220197378 